\title{
Quantitation of Human Immunodeficiency Virus Provirus and Circulating Virus: Relationship with Immunologic Parameters
}

\author{
S. Yerly, E. Chamot, B. Hirschel, and L. H. Perrin
}

Central Laboratory of Virology, Division of Infectious Diseases, and Medical Outpatient Clinic, Geneva University Hospital, Switzerland

\begin{abstract}
Virologic and seroimmunologic parameters were determined in 56 persons infected with human immunodeficiency virus (HIV). The provirus level varied from 10 to $100,000 / 10^{6} \mathrm{CD4}^{+}$ lymphocytes, and genomic HIV RNA was detectable in 39 of 56 patients at a relative concentration varying from 10 to $>250$ copies $/ \mathrm{mL}$ of serum. Provirus expressed as copies per $10^{6} \mathrm{CD4}^{+}$ lymphocytes and as circulating virus per milliliter of serum increased with disease progression and decrease of $\mathrm{CD}^{+}$cell concentration. The mean provirus concentration expressed per milliliter of blood varied little among categories of patients with various levels of $\mathrm{CD}^{+}$cells, but there was a progressive increase of circulating HIV genomic RNA. These virologic data suggest that during the course of HIV infection, an increasing proportion of the remaining $\mathrm{CD}^{+}$lymphocytes harbor the HIV genome and produce infectious virus. Finally, there was a marked correlation between increased provirus and genomic RNA concentration and three seroimmunologic markers: decrease in $\mathrm{CD}^{+}$cell count, p24 antigenemia, and disappearance of antibodies to HIV core antigen.
\end{abstract}

Human immunodeficiency virus (HIV) induces a persistent infection that progresses slowly from asymptomatic infection to AIDS. Antiretroviral therapy may delay progression. The identification of factors that correlate with progression or regression of HIV infection is important for prognosis and for the monitoring of treatment.

$\mathrm{CD}^{+}$lymphocytes are the main target of HIV infection [1], and the decline in $\mathrm{CD}^{+}$cell concentration is the best predictive factor for progression to AIDS. Other markers with predictive value are 24 antigenemia, antibodies to HIV core antigen (anti-core), and serum levels of neopterin and $\beta_{2}$-microglobulin $[2,3]$. Previous studies [4-6] have attempted to detect HIV itself in plasma and in peripheral blood mononuclear cells (PBMC) and demonstrated, using appropriate coculture techniques, that viremia is present in most infected patients and that the virus load increases with disease progression. In clinical trials, the biologic effects of antiviral therapy are assessed mainly by counting $\mathrm{CD} 4^{+} \mathrm{lym}-$ phocytes and by measuring $\beta_{2}$-microglobulin and p24 antigenemia [7-9]. Quantitative determination of infectious HIV in PBMC and plasma is expensive and technically demanding; it has therefore been done in only a few investiga-

Received 16 December 1991; revised 12 March 1992.

Informed consent was obtained from all participants, and human experimental guidelines of the US Department of Health and Human Services and of the Ethical Local Committee were followed.

Financial support: Swiss Federal Office of Public Health (Cohort Study, Part A) and the National AIDS Research Program.

Reprints or correspondence: Dr. Luc Perrin, Central Laboratory of Virology. Geneva University Hospital, 1211 Geneva 4, Switzerland.

The Journal of Infectious Diseases 1992;166:269-76

(C) 1992 by The University of Chicago. All rights reserved. $0022-1899 / 92 / 6602-0007 \$ 01.00$ tions, in which viremia usually decreased after zidovudine therapy $[4,5]$.

The polymerase chain reaction (PCR) offers a simple method to quantify proviral HIV DNA and genomic HIV RNA. The aim of this study was to determine virologic parameters in a large group of patients with various clinical presentations and to analyze the relationship between virologic parameters, such as provirus and circulating virus, and seroimmunologic parameters.

\section{Patients and Methods}

Study population. Fifty men and 6 women with serum antibodies to HIV-I participated. Eleven were asymptomatic (Centers for Disease Control [CDC] stage II); 21 had persistent generalized lymphadenopathy (CDC stage III); 12 had CDC stage IV disease (10, IV-C-2; 2, IV-D, analyzed together); and 12 had CDC stage IV-C- 1 disease [10]. The mean CD4 $4^{+}$lymphocyte counts in these four subgroups were $497,481,254$, and $45 / \mu \mathrm{L}$, respectively. Negative control samples were collected from 20 blood donors with no antibodies to HIV-1. A number of participants were on zidovudine treatment: 2 with CDC stage II disease ( 55 and 33 days), 1 with stage III ( 165 days), 3 with stage IV-C- 2 or IV-D ( 48,65 , and 766 days), and 7 with stage IV-C-1 $(83,120,139,308,386,572$, and 659 days).

Seroimmunologic data. EDTA-treated blood $(10-20 \mathrm{~mL})$ and native blood $(10 \mathrm{~mL})$ were collected from the participants by venipuncture and processed within $4 \mathrm{~h}$. Native blood samples were centrifuged at $1500 \mathrm{~g}$ for $10 \mathrm{~min}$, and sera were aliquoted and frozen at $-70^{\circ} \mathrm{C}$. Complete blood count was done, and the absolute concentrations of $\mathrm{CD} 3, \mathrm{CD} 4$, and CD8 lymphocytes were determined by flow cytometry (Coulter EPICS IV; Instrumente Gesellschaft, Basel, Switzerland) using fluoresceinated OKT3, OKT4a, and OKT8 monoclonal antibodies (Orthomune; Ortho Diagnostics, Raritan, NJ). HIV-1-specific antibod- 
ies were determined by EIAs (Abbott recombinant HIV-1/HIV2 EIA and Envacor, Abbott Laboratories, Abbott Park, IL) and Western blot (Du Pont, Geneva). Levels of p24 antigen were measured in duplicate, and positive samples were neutralized with antibodies to HIV-1 (HIVAG-1; Abbott). Serum $\beta_{2}$-microglobulin levels were determined using a commercial assay (IMX $\beta_{2}$-Microglobulin; Abbott). All the ElAs were done in batch testing.

Semiquantitation of HIV provirus. PBMC were isolated by Ficoll-Paque (Pharmacia, Dubendorf, Switzerland). The pellet containing $1-20 \times 10^{6} \mathrm{PBMC}$ was incubated overnight at $37^{\circ} \mathrm{C}$ in a lysis buffer containing $100 \mathrm{mM} \mathrm{NaCl}, 50 \mathrm{~m} M$ TRIS-HCl (pH 7.5), $1 \mathrm{~m} M$ EDTA, $0.5 \% \mathrm{SDS}$, and $100 \mu \mathrm{g} / \mathrm{mL}$ proteinase $\mathrm{K}$. After phenol-chloroform extraction, DNA was precipitated with ethanol and resuspended in TE buffer ( $10 \mathrm{~m} M$ TRIS-HCl, $\mathrm{pH} 7.5,1 \mathrm{~m} M$ EDTA). The LAV-8E5 cell line (National Institute of Allergy and Infectious Diseases, AIDS Research and Reference Reagent Program, Bethesda, MD) containing one copy of HIV-1 provirus per cell was grown in culture as recommended [11]. DNA was extracted from a pellet of $50 \times 10^{6}$ cells and serially diluted in HIV-negative human genomic DNA to obtain the equivalent of $1-1000$ LAV-8E5 cells in $1 \mu \mathrm{g}$ of human genomic DNA $/ 10 \mu \mathrm{L}$. For provirus amplification, a 238-bp segment of a conserved region of the HIV-1 pol gene was selected and amplified [12]. All samples were tested in duplicate using $1 \mu \mathrm{g}$ of genomic DNA corresponding to 150,000 cells/test. The reaction mixture of $100 \mu \mathrm{l}$ containing $1 \mu \mathrm{g}$ of genomic DNA and 2.5 units of DNA polymerase (Amplitaq; PerkinElmer Cetus, Norwalk, CT) was adjusted to $10 \mathrm{~m} M$ TRIS-HCl (pH 8.3), $50 \mathrm{mM} \mathrm{KCl}, 2.5 \mathrm{mM} \mathrm{MgCl}_{2}, 0.5 \mathrm{mM}$ of each deoxynucleoside triphosphate (dNTP), 0.5 $\mu M$ of POL 1 and POL 2 primers (POL 1,5'-TGGGTACCAGCACACAAAGG, 37343753 in HIV BRU; POL 2.5'-ACTTGTCCATGCATGGCTTC, 3953-3972 in HIV BRU) [13]. The reaction was cycled 37 times $\left(94^{\circ} \mathrm{C}, 1 \mathrm{~min} ; 56^{\circ} \mathrm{C}, 1.5 \mathrm{~min} ; 72^{\circ} \mathrm{C}, 1 \mathrm{~min}\right)$ using a DNA thermal cycler (model 480; Perkin-Elmer Cetus) [12]. Five samples of human genomic DNA containing $1,3,10,100$, and 1000 copies of HIV provirus from the LAV-8E 5 cells were included in each experiment.

The denatured PCR product was applied to nylon membrane (GeneScreenPlus; NEN, Boston) using a vacuum filtration apparatus (Minifold II; Schleicher \& Schuell, Keene, NH). Filters were incubated for $1 \mathrm{~h}$ at $45^{\circ} \mathrm{C}$ in prehybridization solution $(4 \times$ SSC [standard sodium citrate], $5 \times$ Denhardt's solution, $5 \%$ SDS, $20 \mathrm{~m} M$ sodium phosphate [pH 7], $100 \mu \mathrm{g} / \mathrm{mL}$ sheared and denatured salmon sperm DNA) and hybridized to a ${ }^{32} \mathrm{P}$-labeled probe (5'-AATTGGAGAGCAATGGCTAGTGA, 3863-3885 in HIV BRU) by incubation at $50^{\circ} \mathrm{C}$ overnight (specific activity, $10^{8} \mathrm{cpm} / \mu \mathrm{g}$ ). Then filters were washed $15 \mathrm{~min}$ at $50^{\circ} \mathrm{C}$, once with $3 \times$ SSC and $0.1 \%$ SDS, once with $0.5 \times$ SSC and $0.1 \%$ SDS, then twice with $0.1 \times$ SSC and $0.1 \%$ SDS. The radioactivity of each spot applied to the nylon membrane was determined using the Phosphorlmager system (Molecular Dynamics, Basel, Switzerland).

The number of HIV proviral copies was calculated in relation to the standard curve generated by using DNA from defined cell equivalent of the LAV-8E5 cell line. To relate the number of proviral copies to $10^{6} \mathrm{CD} 4$ cells, the number of copies measured in $1 \mu \mathrm{g}$ of DNA corresponding to 150,000 cells was multiplied by a correcting factor (6.66) and further divided by the ratio of CD4 cells per microliter to total lymphocytes per microliter. We have shown previously that the sensitivity of proviral HIV DNA detection is on the order of one proviral copy per sample [12, 13]. The one-copy samples were detected in 6 of 14 experiments and three copies in at least one of the two duplicate amplifications in all assay runs. Negative samples (serum from HIV-seronegative blood donors included in each run) gave numbers (pixels) nearly the same as the background value measured on the membrane in the absence of DNA. Reference samples with the equivalent of one proviral copy gave numbers at least twice the background value. The coefficient of correlation between points of the standard curve is typically $\sim 0.98$. Interassay variation, checked using 10 different samples in three different experiments, was $30 \%$; intraassay variation was $19 \%$.

HIV RNA semiquantitation. Circulating genomic HIV RNA was detected after immunocapture of the virus, reverse transcription (RT), and cDNA amplification. To prepare the immunoabsorbent, IgG was purified from $35 \mathrm{~mL}$ of pooled sera from 10 patients with a high titer of anti-HIV-1 antibodies and no circulating antigen by ammonium sulfate precipitation [14] and diethylaminoethyl cellulose chromatography. $\operatorname{IgG}(200 \mathrm{mg})$ was coupled to $5 \mathrm{~g}$ of cyanogen bromide-activated Sepharose 4B (Pharmacia) according to the manufacturer's recommendations. The final step was extensive washing with $2 \mathrm{~L}$ of $2 \%$ Nonidet P-40 (NP40) in TE buffer. The coupling efficacy was $75 \%$. Sepharose was stored in PBS plus $0.02 \% \mathrm{NaN}_{3}$ at $4^{\circ} \mathrm{C}$.

Immunocapture of circulating virus was achieved as follows: $100 \mu \mathrm{L}$ of frozen serum or dilutions was adjusted to $200 \mu \mathrm{L}$ with $150 \mathrm{mM} \mathrm{NaCl}$ and incubated on a rotator overnight at $4^{\circ} \mathrm{C}$ with $20 \mu \mathrm{L}$ of $5 \%$ Sepharose suspension (a threefold excess as determined in preliminary experiments). The Sepharose particles were pelleted, washed twice with $150 \mathrm{~m} M \mathrm{NaCl}$, suspended in 5 $\mu \mathrm{L}$ of $1 \% \mathrm{NP} 40$, and heated at $95^{\circ} \mathrm{C}$ for $5 \mathrm{~min}$. RT was done in $20 \mu \mathrm{L}$ containing $50 \mathrm{~m} M$ TRIS- $\mathrm{HCl}(\mathrm{pH} 8.3), 20 \mathrm{~m} M \mathrm{KCl}, 6$ $\mathrm{mM} \mathrm{MgCl}_{2}, 1 \mathrm{mM}$ of each dNTP, 25 units of RNase inhibitor (Boehringer, Mannheim, Germany), 100 pmol of $\mathrm{dN}_{6}$ random primers (Boehringer), and 200 units of Moloney murine leukemia virus reverse transcriptase (BRL, Bethesda, MD). The mixture was incubated $10 \mathrm{~min}$ at room temperature and $1 \mathrm{~h}$ at $42^{\circ} \mathrm{C}$, heated to $95^{\circ} \mathrm{C}$ for $15 \mathrm{~min}$, then $2 \mu 1$ of $0.05 \mathrm{mg} / \mathrm{mL}$ solution of proteinase $\mathrm{K}$ (Sigma, St. Louis) was added. The mixture was incubated at $55^{\circ} \mathrm{C}$ for $30 \mathrm{~min}$, heated to $95^{\circ} \mathrm{C}$ for 15 min, and cooled to $4^{\circ} \mathrm{C}$. Next, cDNA was amplified as described above for provirus amplification.

Circulating genomic HIV RNA was measured semiquantitatively by using serial dilutions of serum in the absorption step. All sera were tested at least twice without dilution $(100 \mu \mathrm{L}$ of serum) and when diluted 10 and 25 times with $150 \mathrm{mM} \mathrm{NaCl}$. Samples positive without dilution were diluted twice and tested singly. Identical results were obtained with duplicate tests for all but 3 samples; these 3 were retested three times, and the result used was the mean of the five determinations. Each set of experiments included a negative control (serum from a blood donor), two known weakly reactive sera, and, for the PCR step, dilutions of LAV-8E5 DNA. The two weakly positive samples (RNA of $<10$ but $>1$ copy $/ \mathrm{mL}$ ) included in each run gave positive results 
Figure 1. HIV provirus levels in relation to circulating genomic RNA. Provirus is expressed as $\log$ of provirus $/ 10^{6} \mathrm{CD} 4^{+}$lymphocytes. Participants are divided into four groups on basis of level of RNA molecules detected/ $\mathrm{mL}$ of serum. Number of participants with various levels of provirus for each category is shown at bottom.

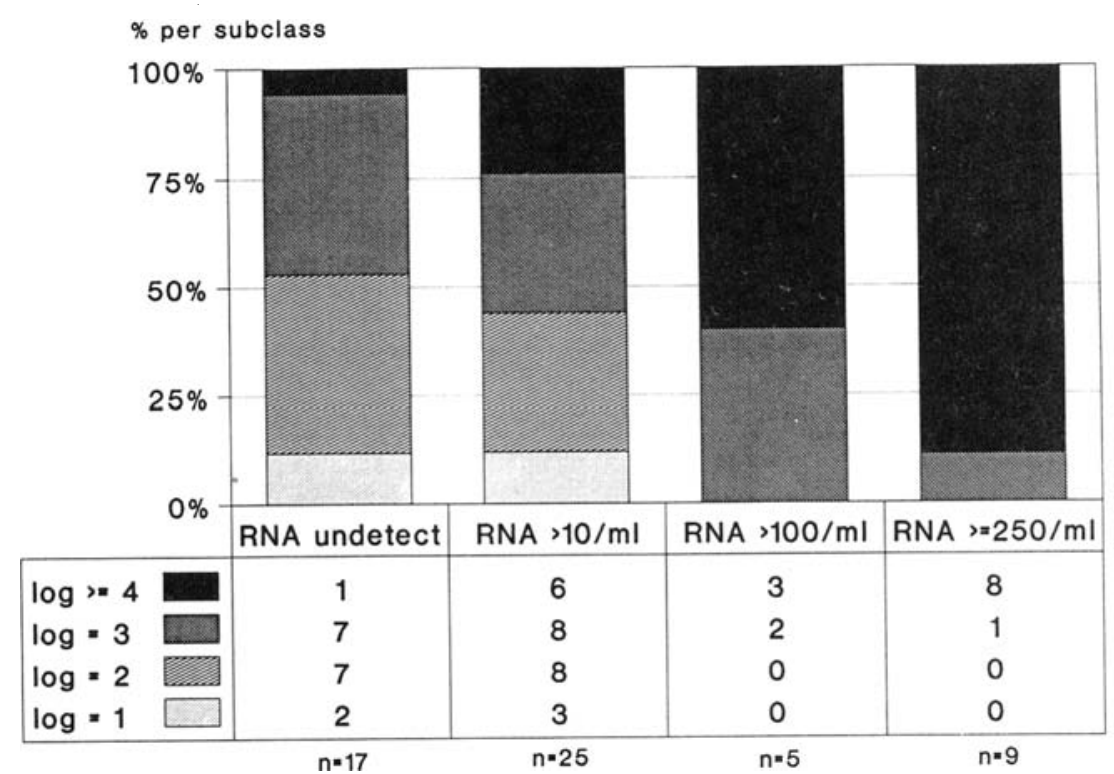

in 14 of 15 experiments. The results of RNA copy number are measured as a function of the dilutions of LAV-8E5 DNA and are expressed as undetectable, $>10$ copies $/ \mathrm{mL}$ (positive signal using $100 \mu \mathrm{L}$ of serum and negative signal using $10 \mu \mathrm{L}$ of serum), $>100$ copies $/ \mathrm{mL}$, and $>250$ copies $/ \mathrm{mL}$. As a control, serum of each participant was absorbed on Sepharose, and the pellet was amplified without the reverse transcriptase step; none gave a positive signal. For determining circulating HIV RNA, $-70^{\circ} \mathrm{C}$ frozen stored sera were tested within 3 months of collection. No decline of HIV RNA level has been observed when serial unthawed samples have been tested repeatedly over 4-6 months.

Statistical analysis. Groups were compared using the $\chi^{2}$ test with Yates's correction or the two-tailed Fisher's exact test.

\section{Results}

Figure 1 presents the relationship between number of proviral copies and concentration of genomic viral RNA in serum. The provirus was detectable in all participants, whereas genomic RNA was detectable in $39(70 \%)$ of 56 . In general, persons with a high number of proviral copies also had high RNA levels. High numbers of proviral copies ( $\geqslant 1000$ copies $/ 10^{6} \mathrm{CD} 4^{+}$lymphocytes) were detected in all participants with $>100$ copies of genomic $\mathrm{RNA} / \mathrm{mL}$ of serum compared with $22(52 \%)$ of 42 participants with $<100$ copies/mL $(P=.008)$.

In figure 2 , provirus and circulating virus are shown in relation to clinical stages. A high number of proviral copies $(\log \geqslant 3)$ was found in $20(83 \%)$ of 24 participants in CDC stages IV-C-2, IV-C-1, or IV-D compared with $16(50 \%)$ of 32 participants in CDC stages II and III $(P=.02)$. More than 100 RNA copies/mL were found in 11 (46\%) of 24 participants with stage IV disease compared with $3(9 \%)$ of 32 participants with stage II or III $(P=.005)$.
The concentration of $\mathrm{CD}^{+}$lymphocytes in the peripheral blood is often used as a prognostic marker. In figure 3 , results are expressed in relation to four categories of $\mathrm{CD}^{+}$cell concentration. Concentrations of provirus per $10^{6} \mathrm{CD}^{+}$lymphocytes and of circulating genomic RNA both increase when the $\mathrm{CD}^{+}$cell count decreases. More than 1000 proviral copies were found in $25(96 \%)$ of 26 participants with $\mathrm{CD}^{+}$cell counts $<200 / \mu \mathrm{L}$ compared with 11 (37\%) of 30 participants with $\mathrm{CD}^{+}$cell counts $>200 / \mu \mathrm{L}(P<.001)$. More than 100 RNA copies $/ \mathrm{mL}$ were found in $13(50 \%)$ of 26 participants with $\mathrm{CD}^{+}$cell counts $<200 / \mu \mathrm{L}$ compared with 1 (3\%) of 30 participants with $\mathrm{CD}^{+}$cell counts $>200 /$ $\mu \mathrm{L}(P<.001)$.

Figure 4 shows concentrations (values) of provirus (DNA) and circulating genomic RNA and the ratio between them for individual subjects. The values are expressed per milliliter of blood, to determine the virus load, and are presented for four categories of $\mathrm{CD}^{+}$concentration. It appears that individual values of provirus vary to a greater extent within each category than do the mean values of the four categories. Furthermore, this does not seem to be linked to zidovudine treatment. In contrast, the percentage of patients with circulating genomic HIV RNA increases markedly in the two groups of participants with $\mathrm{CD}^{+}$cell counts $<200 / \mu \mathrm{L}$ compared with those with $>200 / \mu \mathrm{L}$.

The ratio of provirus to circulating genomic RNA (also shown in figure 4) indicates that the concentration of provirus exceeds the concentration of circulating virus until late in the disease (participants with $\mathrm{CD} 4^{+}$cell counts $<50 / \mu \mathrm{L}$ ).

In figures 5-7, concentrations of provirus and circulating genomic RNA are reported in relation to presence or absence of p24 antigen, to high or medium level of or absence of anti-p24 antibodies, and to $\geqslant 3$ or $<3 \mathrm{mg} / \mathrm{mL} \beta_{2}$-microglobulin. Associations were found between virologic parame- 

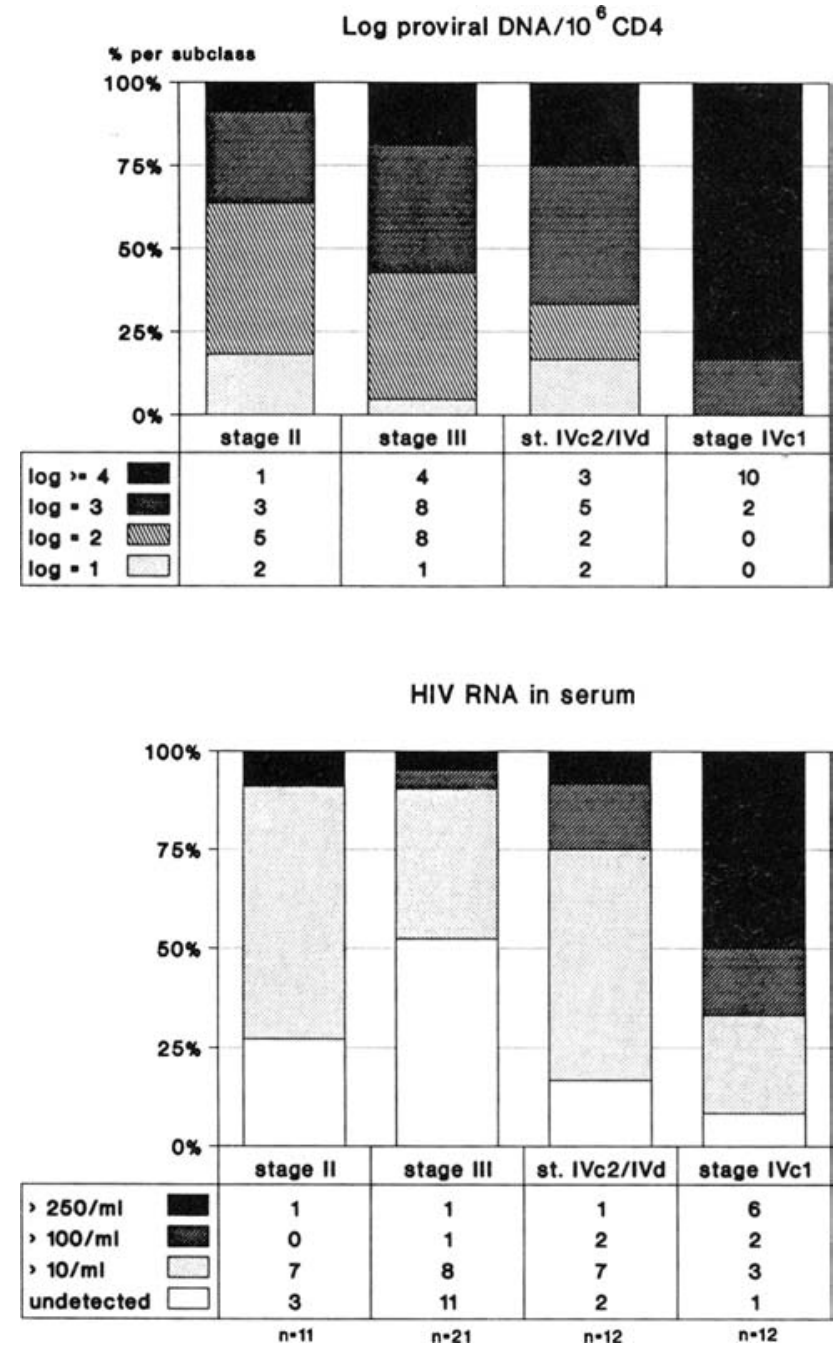

Figure 2. HIV load in relation to disease stage according to Centers for Disease Control (CDC) classification. Top, number of proviral copies in different CDC stages. Results of provirus (DNA) are expressed as $\log$ of provirus per $10^{6} \mathrm{CD}^{+}$lymphocytes. Bottom, number of RNA molecules/mL of serum for different CDC stages. Results of circulating genomic HIV RNA are reported as undetectable, $>10$ molecules $/ \mathrm{mL},>100$ molecules $/ \mathrm{mL}$, and $>250$ molecules $/ \mathrm{mL}$. Number of participants is shown at bottom of each graph.

ters and both p24 antigen and anti-p24 antibodies but not $\beta_{2}$-microglobulin. As shown in figure $5,>1000$ copies of HIV provirus $/ 10^{6} \mathrm{CD} 4^{+}$lymphocytes were detected in 20 $(91 \%)$ of 22 participants with p24 antigen compared with 16 (47\%) of 34 participants without p24 antigen $(P=.002)$. More than 100 RNA copies/mL were found in $11(50 \%)$ of 22 participants with $\mathrm{p} 24$ antigen compared with $3(9 \%)$ of 34 participants without p24 antigen $(P=.002)$. As shown in figure $6,>1000$ copies of provirus were found in $17(94 \%)$ of 18 participants without anti-p24 antibodies compared with $19(50 \%)$ of 38 participants with anti-p24 antibodies $(P=$ $.006)$. More than 100 RNA copies/mL were found in 9
(50\%) of 18 participants without anti-p24 antibodies compared with $5(13 \%)$ of 38 participants with anti-p24 antibodies $(P=.007)$. However, the associations were far from perfect; for example, $50 \%$ of p 24 antigen-negative subjects had detectable circulating genomic RNA, and some participants with high levels of anti-core antibodies had high levels of provirus and circulating RNA.

Only limited follow-up was available after these tests (between September 1990 and May 1991). Five subjects have died ( 21 days, 91 days, 105 days, 7 months, and 8 months) since completion of this investigation. All had $>250$ copies/ $\mathrm{mL}$ circulating genomic RNA (of 9 total subjects with $>250$ copies $/ \mathrm{mL}$ ) and $>10^{4}$ copies of provirus $/ 10^{6} \mathrm{CD}^{+}$cells (of 18 total subjects with that level). Their $\mathrm{CD}^{+}$cell counts at the time of the investigation were $2,7,8,16$, and $71 / \mu \mathrm{L}$.
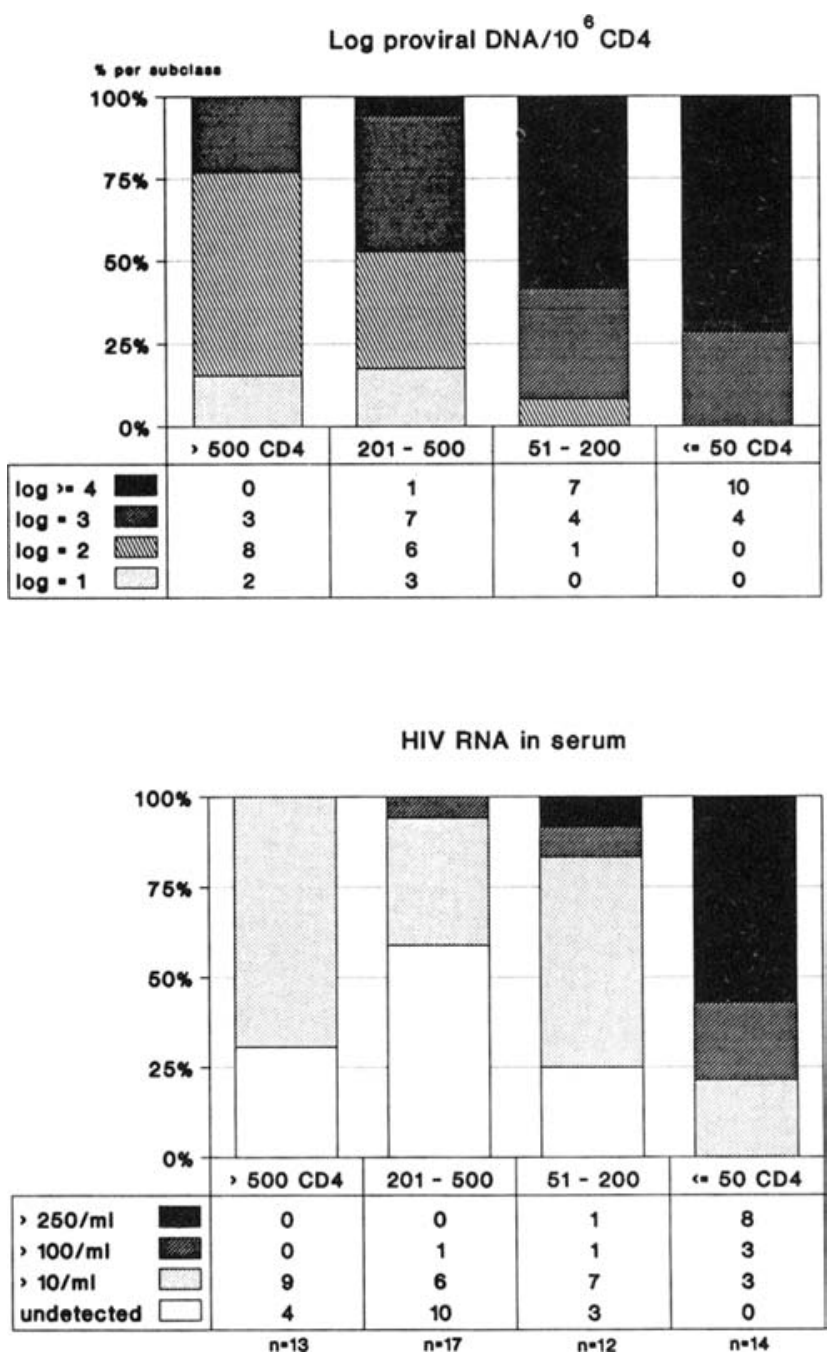

Figure 3. HIV load in relation to $\mathrm{CD} 4^{+}$lymphocytes $/ \mu \mathrm{L}$. Participants are divided into four groups according to concentration of $\mathrm{CD} 4{ }^{+}$in peripheral blood. Number of $\mathrm{CD} 4^{+}$cells in each category is shown at bases of columns. Results of provirus and circulating HIV RNA are expressed as in figure 2. 
Figure 4. HIV provirus copies (DNA) and circulating HIV RNA/ $\mathrm{mL}$ of blood and ratio of provirus to HIV RNA. Values of circulating HIV RNA have been adjusted for hematocrit of $40 \%$ (RNA/mL values divided by 2.5 ). For determination of ratio of DNA to RNA, value of I ( 1 copy of $R N A / m L$ of blood, concentration of RNA not detectable in our system) has been attributed to samples with undetectable circulating RNA. Participants are grouped according to $\mathrm{CD} 4^{+}$ concentration. $O$, participants not treated with zidovudine; 9 , participants treated with zidovudine; $\boldsymbol{\Delta}$, ratio of provirus divided by $\mathrm{HIV}$ RNA; horizontal bars, mean value.

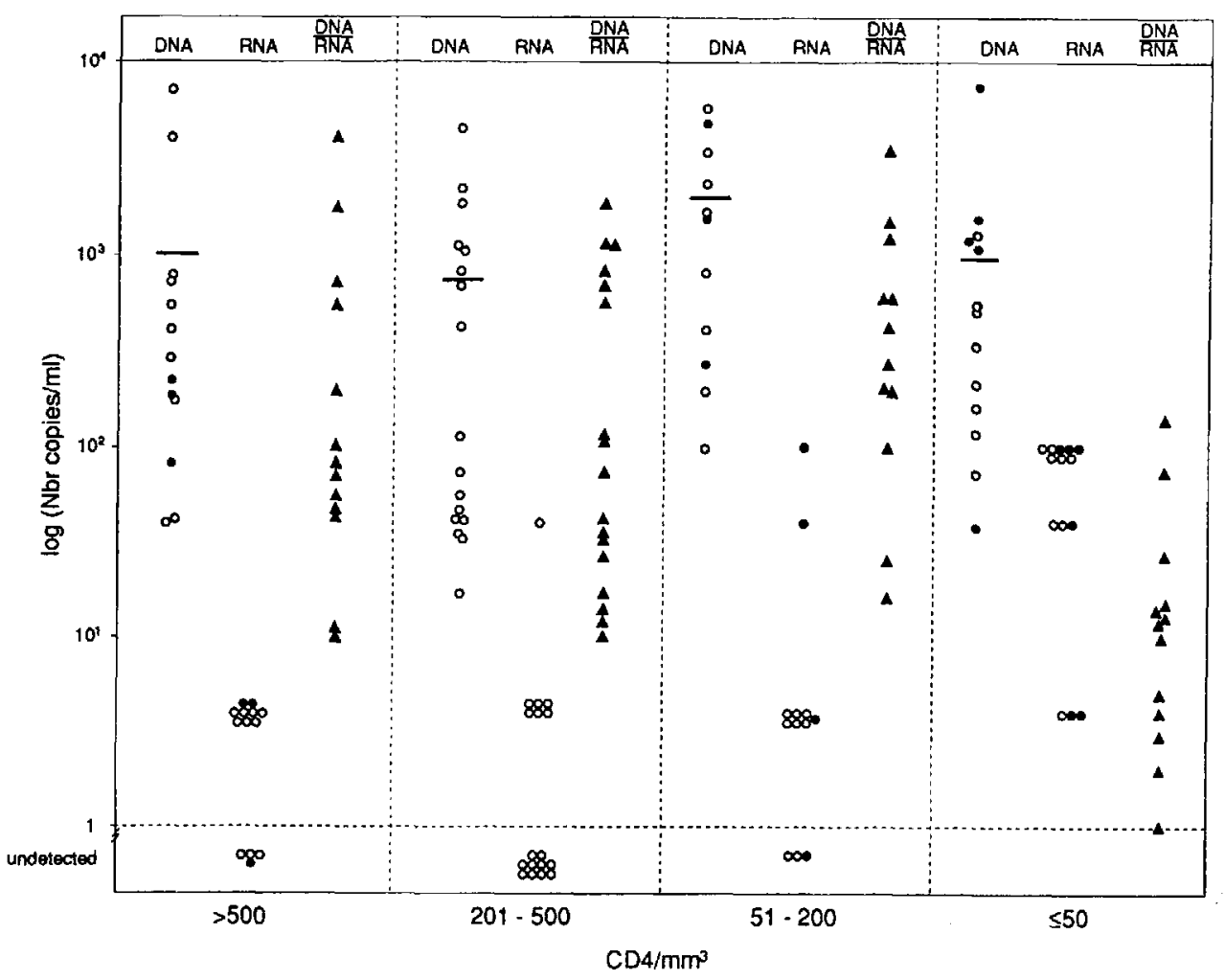

\section{Discussion}

In this study, a close association was observed between virologic parameters and seroimmunologic markers commonly used for the evaluation of HIV infection, such as $\mathrm{CD}^{+}$lymphocytes, 24 antigenemia, and anti-core antibodies.

The virologic parameters selected explore different aspects. Semiquantitation of the provirus is related to the reservoir of HIV, although cell types not represented in the peripheral blood (such as Langerhans cells) may be an important reservoir of HIV [15]. Circulating genomic RNA reflects viremia and is linked not only to viral replication but also to viral clearance, which may be more efficient in early stages of HIV infection. The result of these two factors (replication and clearance of HIV) as determined by circulating genomic RNA is a sensitive index of the quantity of HIV available for propagation of the infection.

The virologic parameters measured in this investigation provided semiquantitative information. The choice of a pol gene segment for HIV DNA amplification was based on the low number of base substitution among HIV isolates in these parts of the pol gene $[12,13]$. A method based on immunocapture of the virus rather than RNA purification was selected for the detection of circulating HIV. For the capture of circulating virus, we used polyclonal (rather than monoclonal) antibodies to HIV to avoid biases linked to sequence variations of gp 120 among HIV isolates. The absorption step is convenient in terms of rapidity, simplicity, specificity (only the virus is absorbed), and suitability for quantitation by limiting dilutions. The main limitation of the quantitation of RNA is linked to the RT step, whose efficacy is 5\% [16] (in contrast, DNA amplification can detect a single copy of provirus $[12,17,18])$. For this reason, it may be more appropriate to express the results of circulating RNA in arbitrary units rather than in number of RNA molecules per milliliter. However, for simplicity of expression and to avoid artificial manipulations of the data, results are expressed in terms of relative concentration of RNA molecules per milliliter. Although they are relative, RNA results are reproducible; they are therefore suitable for comparative studies.

When the provirus measurements were regarded in relation to $10^{6} \mathrm{CD}^{+}$lymphocytes, we observed, as have others, an increase of proviral copies with progression of HIV infection and with the decrease in $\mathrm{CD}^{+}$cell concentration $[3,4$, $17,19-21]$. Only a few copies of provirus are detectable in each infected PBMC [17], so our results suggest there is a progressive increase in the percentage of cells carrying the provirus that may reach $10 \%$. The other mode of expressing the number of proviral copies per milliliter of blood reflects the absolute concentration of the provirus and is a better estimate of the HIV reservoir in $\mathrm{CD}^{+}$lymphocytes. During the progression of HIV infection, the mean concentration of provirus per milliliter of blood increases by only a factor of three for subjects with the lowest concentrations of $\mathrm{CD} 4^{+}$ lymphocytes. Greater variations are observed among individ- 

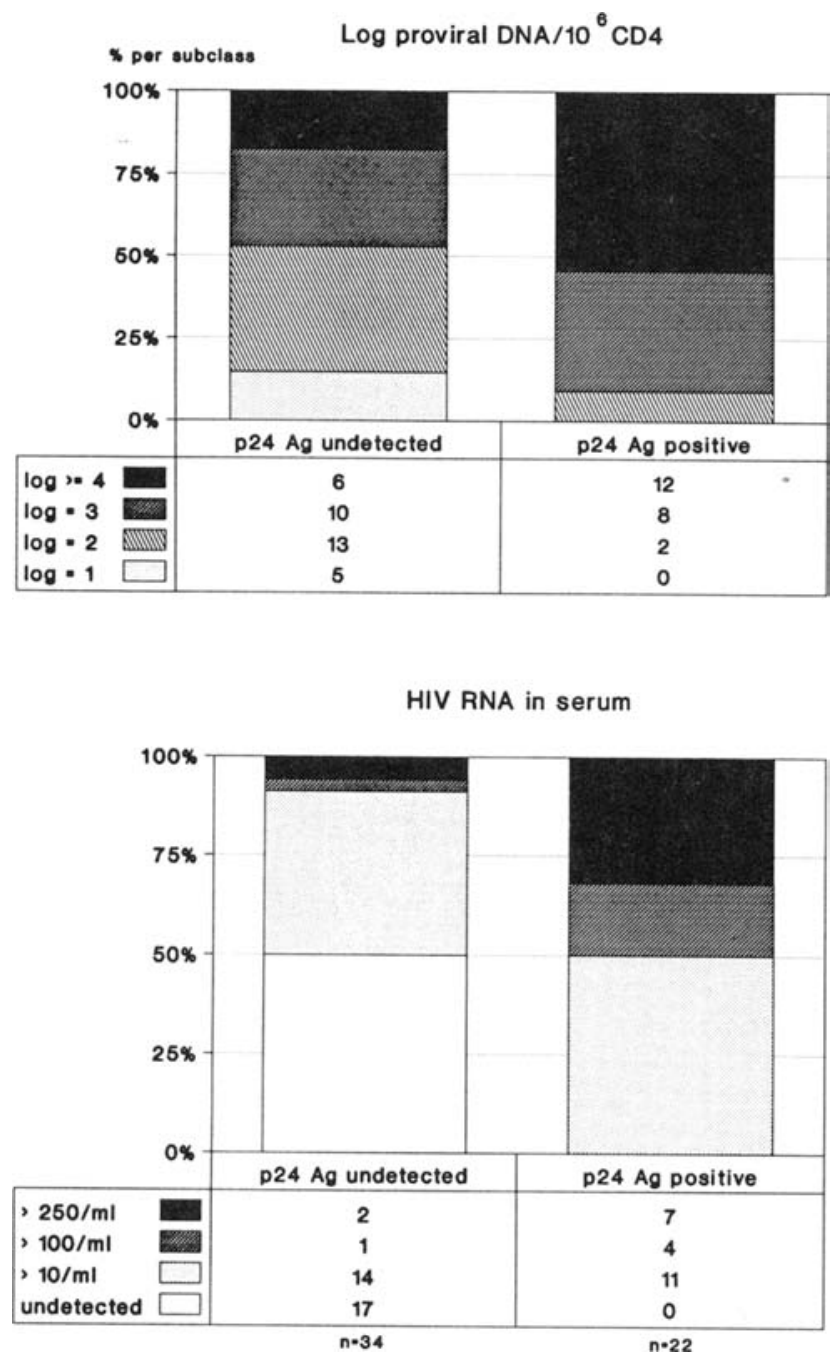

Figure 5. HIV load in relation to p24 antigenemia (p24 Ag). Participants are divided into those without and those with p24 Ag. Results of provirus and circulating HIV RNA are expressed as in figure 2 .

uals, and these are relatively independent of their $\mathrm{CD}^{+}$cell counts. All together, these data suggest that in peripheral blood the increase in percentage of cells carrying the provirus is counterbalanced by a decrease in the concentration of cells susceptible to HIV infection during the progression of HIV infection. In addition, in the present investigation, values determined in participants on zidovudine (most of them on long-term zidovudine, mean duration of 261 days) did not differ significantly from those not on zidovudine.

Circulating genomic RNA was detected in $70 \%$ of the participants. The proportion of subjects with detectable genomic RNA and the amount of genomic RNA increased with progression of HIV infection. These results are compatible with those of earlier investigations using a coculture detec- tion system $[3,4,6,19,22]$. For example, in one large study, the percentage of plasma coculture positivity varied from $23 \%$ in asymptomatic participants to $82 \%$ in patients with AIDS [3]. The marked variation in concentration of infectious virus reported by different groups using HIV culture $[3,4,19]$ underlines the need of alternative approaches for the analysis of virologic parameters. Recently, Zang et al. [16], using an RNA PCR assay, detected circulating genomic RNA in $100 \%$ of individuals with AIDS-related complex and in $60 \%$ of asymptomatic individuals. Other investigators have reported a correlation between disease stage and viral RNA in serum $[22,23]$, as was seen in the present study.

Participants with $\mathrm{CD} 4^{+}$counts $>200 / \mu \mathrm{L}$ can be divided into two subgroups: those without detectable circulating
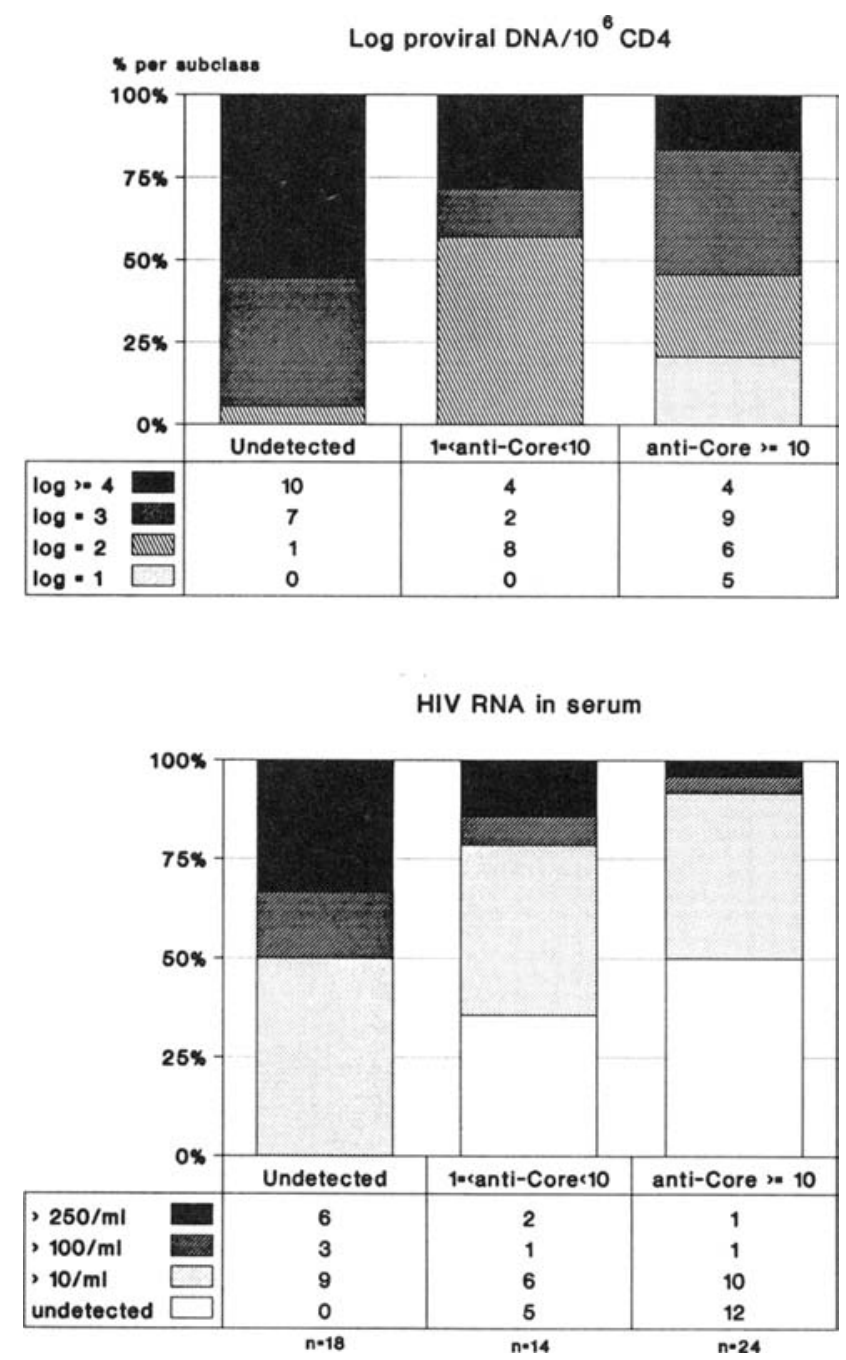

Figure 6. HIV load in relation to antibodies to HIV core antigen (anti-core). Participants are divided into those without detectable anti-core antibodies (undetected) and those with low (index, 1-10) and high levels of anti-core antibodies (index, $\geqslant 10$ ). Results of provirus and circulating HIV RNA are expressed as in figure 2. 


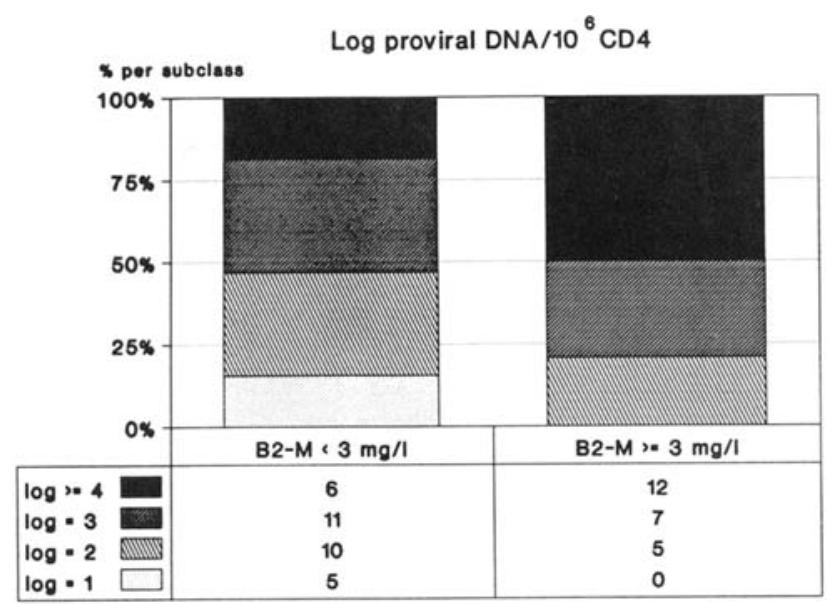

HIV RNA in serum

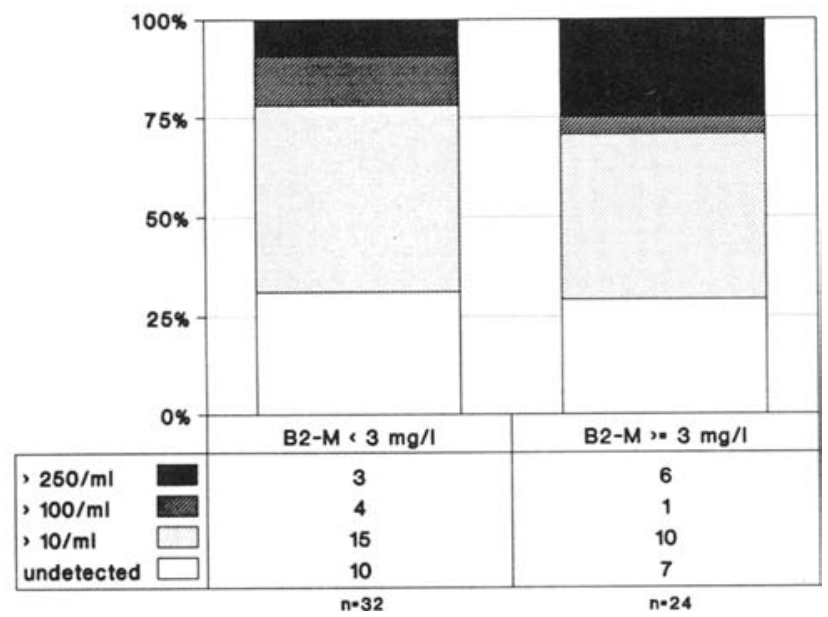

Figure 7. HIV load in relation to $\beta_{2}$-microglobulin. Participants are grouped according to level of $\beta_{2}$-microglobulin; limit of $3 \mathrm{mg} / \mathrm{L}$ was arbitrarily selected and corresponds to $250 \%$ of mean value of healthy adults. Results of provirus and circulating HIV RNA are expressed as in figure 2 .

RNA (14 participants) and those with RNA [16]. It is tempting to speculate that the patients with circulating RNA are at higher risk for rapid progression of HIV infection and that they would benefit most from antiviral treatment. Verification of this hypothesis will require long prospective studies. Ours was a cross-sectional study with only 9 months of follow-up. During this period, 5 subjects with $>250$ circulating RNA molecules $/ \mathrm{mL}$ died, emphasizing the negative prognostic value of high levels of circulating genomic RNA.

A positive association between circulating genomic HIV RNA and p24 antigenemia was observed; this indirectly validates the techniques used for RNA determination. All p24 antigen-positive but only $50 \%$ of p 24 antigen-negative subjects were found to be RNA-positive. As expected, an inverse association is observed with anti-core antibodies. The detection of genomic HIV RNA in participants with high levels of anti-core antibodies is not surprising, since immunocapture is designed to capture intact virus whose surface component is gp 160 and its process products. The absence of association with $\beta_{2}$-microglobulin, whose increase has been shown to correlate with progression of AIDS [24,25], may be due to a preferential link of $\beta_{2}$-microglobulin increase with cell activation rather than with HIV multiplication itself. In this context, $\beta_{2}$-microglobulin levels may be more influenced by opportunistic infections than by HIV load.

In conclusion, the present investigation demonstrated a closed association of virologic parameters with $\mathrm{CD}^{+}$concentration, p24 antigen, and anti-core antibodies. It also shows that a high proportion of participants with $\mathrm{CD}^{+}$cell counts $>200 / \mu \mathrm{L}$ already have high levels of provirus and circulating genomic RNA; these individuals may benefit most from early antiviral therapy. Finally, the technique of semiquantitation of circulating genomic HIV RNA is specific and relatively simple and should be of value in monitoring the effect of antiviral drugs.

\section{Acknowledgments}

We are indebted to T. M. Folks and the AIDS Research and Reference Reagent Program (Division of AIDS, National Institute of Allergy and Infectious Diseases, Bethesda, MD) for providing the LAV-8E5 cell line, to all of the physicians who referred patients to our study, to Denis Hochstrasser (numeric imaging group, University Cantonal Hospital, Geneva) for assistance with the Phosphorlmager, to Alison Heald for reviewing the manuscript, to Victor Gabriel for assistance with the statistical analysis, to Patrick Schreiber for technical help, and to Christine Brown for preparation of the manuscript.

\section{References}

1. Schnittman SM, Psallidopoulos MC, Lane HC, et al. The reservoir for HIV-1 in human peripheral blood is a T cell that maintains expression of CD4. Science 1989;245:305-8.

2. Fayey JL, Taylor JMG, Detels R, et al. The prognostic value of cellular and serologic markers in infection with human immunodeficiency virus type 1. N Engl J Med 1990;322:166-72.

3. Coombs RW, Collier AC, Allain JP, et al. Plasma viremia in human immunodeficiency virus infection. N Engl J Med 1989;321:162631.

4. Ho DD, Moudgil T, Alam M. Quantitation of human immunodeficiency virus type 1 in the blood of infected persons. $N$ Engl $J$ Med 1989;321:1621-5.

5. Jackson JB, Coombs RW, Sannerud K, Rhame FS, Balfour HH. Rapid and sensitive viral culture method for human immunodeficiency virus type 1. J Clin Microbiol 1988;26:1416-8.

6. Ehrnst A, Sönnerborg A. Bergdahl S, Strannegard O. Efficient isolation of HIV from plasma during different stages of HIV infection. J Med Virol 1988;26:23-32.

7. Fischl MA, Richmann DD, Hansen N, et al. The safety and efficacy of zidovudine (AZT) in the treatment of subjects with mildly symptom- 
atic human immunodeficiency virus type 1 (HIV) infection. Ann Intern Med 1990;1 12:727-37.

8. Volberding PA, Lagakos $\$$, Koch MA. et al. Zidovudine in asymptomatic human immunodeficiency virus infection. $N$ Engl $J$ Med 1990;322:941-9.

9. Jacobson MA, Abrams DI, Volberding PA, et al. Serum $\beta_{2}$-microglobulin decreases in patients with AIDS or ARC treated with azidothymidine. J Infect Dis 1989;159:1029-36.

10. Centers for Disease Control. Revision of CDC surveillance case definition for acquired immunodeficiency syndrome. MMWR 1987; 36(suppl S):3S-15.

11. Folks TM, Powel D. Lightfoote M, et al. Biological and biochemical characterization of a cloned LEU-3-cell surviving infection with the acquired immune deficiency syndrome retrovirus. J Exp Med 1986; 164:280-90.

12. Yerly S. Chamot E, Deglon JJ, Hirschel B. Perrin LH. Absence of chronic HIV infection without seroconversion in intravenous drug users. A prospective and retrospective study. J Infect Dis 1991:164:965-8.

13. Perrin LH, Yerly S. Adami N, et al. Human immunodeficiency virus DNA amplification and serology in blood donors. Blood 1990; 76:641-5.

14. Weir D. Handbook of experimental immunology. Vol 1. Immunochemistry. Cambridge, MA: Blackwell Scientific Publications, 1973:6.16.11 .

15. Tschachler E, Groh V. Popovic M, et al. Epidermal Langerhans cellsa target for HTLV-III/LAV infection. J Invest Dermatol 1987;88:223-7.

16. Zang LQ, Simmonds P, Ludlam CA, Leigh Brown AJ. Detection, quantification and sequencing of HIV-I from the plasma of seropositive individuals and from factor VIII concentrates. AIDS 1991;5:675-8I.
17. Simmonds P. Peutherer JF, Ludlam CA, Bishop JO, Leigh Brown AJ. Human immunodeficiency virus-infected individuals contain provirus in small numbers of peripheral mononuclear cells and at low copy numbers. J Virol 1990;64:864-72.

18. Kellogg DE, Sninsky J, Kwok S. Quantitation of HIV-I proviral DNA relative to cellular DNA by the polymerase chain reaction. Anal Biochem 1990; 189:202-8.

19. Saag MS, Crain MJ, Decker WD, et al. High level viremia in adults and children infected with human immunodeficiency virus: relation to disease stage and $\mathrm{CD}^{+}$lymphocyte levels. J Infect Dis 1991; 164:72-80.

20. Lee TH, Sunzeri FJ, Tobler LH, Williams BG, Busch MP. Quantitative assessment of HIV-I DNA load by coamplification of HIV-1 gag and HLA-DQ- $\alpha$ genes. AIDS 1991;5:683-91.

21. Schnittman SM, Greenhouse JJ, Psallidopoulos MC. et al. Increasing viral burden in $\mathrm{CD} 4^{+}$cells from patients with human immunodeficiency virus (HIV) infection reflects rapidly progressive immunosuppression and clinical disease. Ann Intern Med 1990;113:438-43.

22. Holodniy M, Katzenstein DA. Sengupta S, et al. Detection and quantification of human immunodeficiency virus RNA in patient serum by use of the polymerase chain reaction. J Infect Dis 1991;163:862-6.

23. Semple M, Loveday C. Weller I, Tedder R. Direct measurement of viraemia in patients infected with HIV-I and its relationship to disease progression and zidovudine therapy. J Med Virol 1991;35:3845.

24. Laceyc JN, Forbes MA. Waugh MA. Cooper EH, Hambling MH. Serum $\beta_{2}$-microglobulin and human immunodeficiency virus infection. AIDS 1987;1:123-7.

25. Moss AR, Bacchetti P, Osmond D, et al. Seropositivity for HIV and the development of AIDS or AIDS related condition: three years followup of the San Francisco General Hospital cohort. BMJ 1988;296:745-50. 